\title{
Ants as indicators of environmental change and ecosystem processes
}

\author{
Yvonne Tiede $^{\mathrm{a}, *}$, Jan Schlautmann ${ }^{\mathrm{a}}$, David A. Donoso ${ }^{\mathrm{b}, 1}$, Christine I.B. Wallis $^{\mathrm{a}, \mathrm{c}}$, \\ Jörg Bendix ${ }^{\mathrm{c}}$, Roland Brandl ${ }^{\mathrm{d}}$, Nina Farwig ${ }^{\mathrm{a}}$ \\ a Philipps-Universität Marburg, Faculty of Biology, Conservation Ecology, Karl-von-Frisch-Straße 8, 35043 Marburg, Germany \\ ${ }^{\mathrm{b}}$ Universidad Técnica Particular de Loja, Museo de Colecciones Biológicas (MUTPL), San Cayetano Alto s/n, Loja, Ecuador \\ c Philipps-Universität Marburg, Faculty of Geography, Laboratory for Climatology and Remote Sensing, Deutschhausstraße 12, 35032 Marburg, Germany \\ d Philipps-Universität Marburg, Faculty of Biology, Department of Ecology, Animal Ecology, Karl-von-Frisch-Straße 8, 35043 Marburg, Germany
}

\section{A R T I C L E I N F O}

\section{Article history:}

Received 13 May 2016

Received in revised form 23 January 2017

Accepted 25 January 2017

Available online 7 February 2017

\section{Keywords:}

Elevational gradient

Species traits

Forest degradation

Path model

Artificial caterpillars

Functional richness

\begin{abstract}
A B S T R A C T
Environmental stressors and changes in land use have led to rapid and dramatic species losses. As such, we need effective monitoring programs that alert us not only to biodiversity losses, but also to functional changes in species assemblages and associated ecosystem processes. Ants are important components of terrestrial food webs and a key group in food web interactions and numerous ecosystem processes. Their sensitive and rapid response to environmental changes suggests that they are a suitable indicator group for the monitoring of abiotic, biotic, and functional changes. We tested the suitability of the incidence (i.e. the sum of all species occurrences at 30 baits), species richness, and functional richness of ants as indicators of ecological responses to environmental change, forest degradation, and of the ecosystem process predation on herbivorous arthropods. We sampled data along an elevational gradient (1000-3000 $\mathrm{m}$ a.s.l.) and across seasons (wetter and drier period) in a montane rainforest in southern Ecuador. The incidence of ants declined with increasing elevation but did not change with forest degradation. Ant incidence was higher during the drier season. Species richness was highly correlated with incidence and showed comparable results. Functional richness also declined with increasing elevation and did not change with forest degradation. However, a null-model comparison revealed that the functional richness pattern did not differ from a pattern expected for ant assemblages with randomly distributed sets of traits across species. Predation on artificial caterpillars decreased along the elevational gradient; the pattern was not driven by elevation itself, but by ant incidence (or interchangeable by ant richness), which positively affected predation. In spite of lower ant incidence (or ant richness), predation was higher during the wetter season and did not change with forest degradation and ant functional richness. We used path analysis to disentangle the causal relationships of the environmental factors temperature (with elevation as a proxy), season, and habitat degradation with the incidence and functional richness of ants, and their consequences for predation. Our results would suggest that the forecasted global warming might support more active and species-rich ant assemblages, which in turn would mediate increased predation on herbivorous arthropods. However, this prediction should be made with reservation, as it assumes that the dispersal of ants keeps pace with the climatic changes as well as a one-dimensional relationship between ants and predation within a food-web that comprises species interactions of much higher complexity. Our results also suggested that degraded forests in our study area might provide suitable habitat for epigaeic, ground-dwelling ant
\end{abstract}

\footnotetext{
* Corresponding author.

E-mail addresses: yvonne.tiede@biologie.uni-marburg.de (Y. Tiede), jan.schlautmann@biologie.uni-marburg.de (J. Schlautmann),

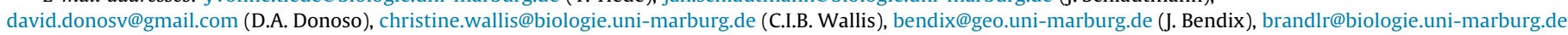
(R. Brandl), nina.farwig@biologie.uni-marburg.de (N. Farwig).

1 Present address: Escuela Politécnica Nacional, Instituto de Ciencias Biológicas, Av. Ladrón de Guevara E11-253 Quito, Ecuador.
} 
assemblages that do not differ in incidence, species richness, functional richness, composition, or predation on arthropods from assemblages of primary forests. Most importantly, our results suggest that the occurrence and activity of ants are important drivers of ecosystem processes and that changes in the incidence and richness of ants can be used as effective indicators of responses to temperature changes and of predation within mega-diverse forest ecosystems.

(c) 2017 Elsevier Ltd. All rights reserved.

\section{Introduction}

Biodiversity provides the basic elements for species interactions within food webs and ecosystem processes and is therefore a key factor for the stability of ecosystems (Cardinale et al., 2012; Chapin III et al., 1997; Tilman et al., 2012). However, rapid anthropogenic environmental and land-use changes increasingly modify the structure and extent of natural ecosystems, which can lead to a dramatic loss of biodiversity (Foley et al., 2005; Walther, 2010). As such, we urgently require a continuous monitoring of the status of biodiversity and ecosystems (Scholes et al., 2008) that not only focuses on the presence or absence of certain (keystone) species, but monitors functional changes in species assemblages and their effects on food webs and ecosystem processes (Noss, 1999; Palmer and Febria, 2012).

Predation is an important process within food webs; predators can act at different trophic levels (De Ruiter et al., 1995) and can modify species abundances (Holt, 1977), composition of assemblages (Pace et al., 1999), and evolution of traits (Peacor and Werner, 2001). Ants are one of the most important generalist predators of arthropods in terrestrial ecosystems, particularly in the tropics (Hölldobler and Wilson, 1990; Seifert et al., 2016). They are crucial for numerous ecosystem processes, e.g., soil turnover, nutrient cycling, plant defense, seed dispersal, and regulation of herbivores, which has led to them being widely accepted as keystone taxa (Parr et al., 2016; Underwood and Fisher, 2006 and references within). Furthermore, their simple and cost-efficient sampling (Andersen and Majer, 2004; Underwood and Fisher, 2006) makes them a suitable indicator of even subtle abiotic, biotic, and functional changes of ecosystems (Folgarait, 1998).

The monitoring of responses to various environmental changes requires measures that match the habitat and degradation type in question (Carignan and Villard, 2002; Dale and Beyeler, 2001; Read and Andersen, 2000; Ricotta et al., 2015; Siddig et al., 2016). Different measures of ant diversity have been successfully used to indicate ecological responses to natural abiotic changes within local habitats, such as temperature, humidity, soil, and vegetation type (Hoffmann, 2010). For ants, species richness alone usually provides rather limited information on ecosystem changes, whereas data on ant abundance, species composition, and richness of functional traits (functional richness) better reflect the biotic response of the entire ecosystem (Folgarait, 1998; Hoffmann and Andersen, 2003; Yates et al., 2014). Many ant species are stenothermic, and thus temperature is often the main determinant of abundance, species richness, and composition of ant assemblages, with generally decreasing ant abundances and species richness with decreasing temperature (Jenkins et al., 2011; Kaspari et al., 2003; Longino et al., 2014; Sanders et al., 2007, 2003). Therefore, the projected global warming might lead to shifts in the latitudinal or elevational distribution of species as well as to an overall loss of species (Colwell et al., 2008; Gibb et al., 2015a,b; Hughes, 2000), with consequences for ant-mediated food web interactions and ecosystem processes (Del Toro et al., 2015). In addition, seasonality influences ant assemblages; high amounts of rainfall can decrease the size of colonies and activity of ants, thereby influencing the composition of assemblages (Andersen, 1986; Delsinne et al., 2013).

Beyond abiotic changes, anthropogenic habitat degradation also alters richness and composition of ant assemblages mediated through changes in habitat characteristics (Hoffmann, 2010; Underwood and Fisher, 2006). In general, a decrease in the complexity of habitats (e.g., the amount or characteristics of leaf litter) leads to changes in species composition (Gibb and Parr, 2013; Gibb et al., 2015b; Wiescher et al., 2012). Thereby, the effect of habitat degradation on ants depends on its type and severity. In complex habitats, such as forests, fragmentation or selective logging does not necessarily affect the abundance or species richness of ants (Donoso, 2017; Underwood and Fisher, 2006 and references within; Woodcock et al., 2011). However, secondary forest patches of differing ages in Brazil contain ant assemblages with fewer species and lower functional diversity compared to old-growth forests (Bihn et al., 2010, 2008). Furthermore, forest degradation is expected to affect the composition of ant assemblages when it is associated with changes in habitat structure, e.g., canopy openness, vegetation structure, and plant richness (Underwood and Fisher, 2006; Yusah and Foster, 2016). In New Guinea, higher density, larger size, and higher taxonomic diversity of trees explains more than $50 \%$ of the observed higher ant species richness of primary forests compared to secondary forests (Klimes et al., 2012).

The multitude of species responses to environmental change depend on the functional traits of species, as traits are related to habitat preference, diet, and foraging strategy (Gibb and Parr, 2013; Gibb et al., 2015b; Wiescher et al., 2012). For example, the overall body size of epigaeic ant assemblages is linked to habitat complexity and trophic level (Gibb and Parr, 2013), where larger ants forage at the surface rather than in the litter (Donoso and Ramón, 2009; Weiser and Kaspari, 2006). Epigaeic predatory ants also have larger bodies than omnivorous species (Gibb et al., 2015b), and head and mandible size are linked to prey size (Davidson, 1977; Fowler et al., 1991; Kaspari, 1996) and leg length is linked to foraging speed (Bartholomew et al., 1988). Given these close relationships of functional traits with habitat conditions and trophic position, it is thought that functional richness of ants is more directly linked with food web interactions and ecosystem processes than species identity per se (Mouchet et al., 2010). However, it is important to note that the strength of an assemblage-wide contribution to ecosystem processes will be determined not only by the number of species and their functional richness but also by the number and activity of individuals (Stuart-Smith et al., 2013).

Abiotic conditions and species traits jointly affect the composition of predator and prey assemblages, which in turn affects predation (Hooper et al., 2005; Lavorel and Garnier, 2002; LebrijaTrejos et al., 2010; Yates et al., 2014). By controlling herbivorous arthropods, predators can positively influence plant growth and regeneration (Snyder et al., 2006) and might promote persistence and stability within assemblages (Chapin III et al., 1997). Overall, rates of predation on herbivorous arthropods decline with increasing elevation, whereby the relative contribution of the various predators might change (Hodkinson, 2005; Sam et al., 2015a). However, estimating predation rates along environmental gradients is 
difficult at ecosystem levels (Parr et al., 2016). To overcome these difficulties, artificial caterpillars have been used in several studies as a simple but effective method to quantify and qualify the predation on herbivorous arthropods. For instance, ants were the most important predators of artificial caterpillars in lowland rainforests of Papua New Guinea, whereas birds were the dominant predators above $1700 \mathrm{~m}$ a.s.l. (Sam et al., 2015a). In addition, the predation pressure on herbivorous arthropods is influenced by seasonal rainfall, with higher attack rates on artificial caterpillars during the wetter season, which is congruent with peaks in real caterpillar density and suggests shifts in the foraging behavior or a timed phenology of the predators (Molleman et al., 2016).

Here we compared the suitability of incidence, species richness, and functional richness of epigaeic ants as indicators of responses to environmental changes and of ecosystem processes, using a simple space-for-time approach (Blois et al., 2013; Pickett, 1989), nutrient baits, and artificial caterpillars. We used elevation as a proxy for temperature changes and accounted also for the effect of wetter and drier seasons and forest degradation. We investigated the relationship between environmental variables and variables characterizing ant assemblages and their functions in food webs. For the latter, we used attack marks of ants on artificial caterpillars as a measure of predation rates. We expected a decline in the incidence and species richness of ants with increasing elevation and that functional richness is a better indicator of predation and forest degradation than the incidence or richness of ants. We used a path model to disentangle the causal relationships of temperature (with elevation as a proxy), season, and habitat degradation with the incidence respectively species richness and functional richness of ants and their consequences for predation.

\section{Methods}

\subsection{Study area}

We conducted our study within and around the Podocarpus National Park ( $4^{\circ} 17^{\prime} 0^{\prime \prime}$ 's $\left.79^{\circ} 0^{\prime} 0^{\prime \prime} \mathrm{W}\right)$ and the Reserva Biológica San Francisco ( $3^{\circ} 58^{\prime} 30^{\prime \prime}$ s $\left.79^{\circ} 4^{\prime} 25^{\prime \prime} \mathrm{W}\right)$ on the eastern Cordillera of the Andes in the provinces of Loja and Zamora-Chinchipe, southern Ecuador. Within the protected areas, the study area is characterized by natural primary forest. Outside of the protected lands, the forest has been mostly converted to active or inert pastures for cattle grazing (Curatola Fernández et al., 2015). This landscape is interspersed with patches of degraded secondary forest. The climate of the study area is perhumid, with a main rainy season occurring from June to August and drier month from October to January (Rollenbeck and Bendix, 2011). Annual rainfall is high throughout the year, with approximately $2000 \mathrm{~mm}$ at $1000 \mathrm{~m}$ a.s.l. (Zamora), $2200 \mathrm{~mm}$ at $2000 \mathrm{~m}$ a.s.l. (ECSF-Met. Station), and $4800 \mathrm{~mm}$ at $3000 \mathrm{~m}$ a.s.l. (Cerro Met. Station; Bendix et al., 2008a, 2008b). The mean annual air temperature decreases with elevation from $20.0^{\circ} \mathrm{C}$ at $1000 \mathrm{~m}$ a.s.l., to $15.5^{\circ} \mathrm{C}$ at $2000 \mathrm{~m}$ a.s.l., to $9.5^{\circ} \mathrm{C}$ at $3000 \mathrm{~m}$ a.s.l. (Bendix et al., 2008a).

\subsection{Study design}

We established 27 study plots along an elevational gradient from 1000 to $3000 \mathrm{~m}$ a.s.l. The plots were located in natural primary forest and in secondary forest fragments at elevational levels of $1000,1500,2000,2500$, and $3000 \mathrm{~m}$ a.s.l. with three replicates per level and type. At the highest elevational level (3000 $\mathrm{m}$ a.s.l.), no forests were degraded, leading to a total of 15 plots in primary forests, and 12 plots in degraded forests. The plots reflected the typical type of natural or degraded forests at the respective elevation level. The natural forest plots comprised evergreen premontane rainforest ( $\sim 1000 \mathrm{~m}$ a.s.l.), evergreen lower montane rainforest ( $\sim 2000 \mathrm{~m}$ a.s.l.), and evergreen upper montane rainforest $(\sim 3000 \mathrm{~m}$ a.s.l.). Outside the protected area, but within the same valley, the degraded plots comprised secondary forest fragments adjacent to active cattle pastures with varying degrees of recent and past reforestations. The degraded forest plots were embedded in a matrix of pastures and bracken-infested areas, interspersed with secondary forest fragments on inaccessible areas, e.g. at steep slopes or crags. The study plots were $1000 \mathrm{~m}^{2}$ in size $(10 \mathrm{~m} \times 100 \mathrm{~m}$ and $20 \mathrm{~m} \times 50 \mathrm{~m}$, depending on the landform configuration), and mean pair-wise geographic distances between study plots ranged from $117 \mathrm{~m}$ to $24 \mathrm{~km}$ (mean \pm SD: $12 \mathrm{~km} \pm 8.4 \mathrm{~km}$ ). Each study plot was subdivided into 5 subplots of $20 \mathrm{~m} \times 10 \mathrm{~m}\left(200 \mathrm{~m}^{2}\right)$.

\subsection{Sampling of ants and data processing}

We sampled ant assemblages during two periods in 2014 (wetter season: April to August; drier season: October, November) following the baiting methods described in Peters et al. (2014). Baiting is an effective technique for recording the occurrence of ant species, especially in habitats with high litter depth (Andersen, 1997). As demands for macronutrients vary and often depend on the trophic position of species, we used six different types of macronutrients to sample ant assemblages. We placed six baits with different nutrients randomly on the ground of each of the five subplots (minimum distance between each set of baits: $5-7 \mathrm{~m}$ ) during times of high ant activity (late morning to early afternoon). The baits consisted of $50 \mathrm{~mL}$ plastic tubes with $15 \mathrm{~mL}$ of one of the following six solutions: $\mathrm{H}_{2} \mathrm{O}$ (tap water; control); $\mathrm{NaCl}(20 \mathrm{~g}$ $\mathrm{NaCl} / 1 \mathrm{~L} \mathrm{H}_{2} \mathrm{O}$ ); amino acid (200 g glutamine/1 $\left.\mathrm{L} \mathrm{H}_{2} \mathrm{O}\right) ; \mathrm{CH}_{2} \mathrm{O}(200 \mathrm{~g}$ sucrose/ $\left.1 \mathrm{LH}_{2} \mathrm{O}\right) ; \mathrm{CH}_{2} \mathrm{O}$-amino acid mix [ $(100 \mathrm{~g}$ sucrose $+100 \mathrm{~g}$ glutamine)/ $1 \mathrm{~L} \mathrm{H}_{2} \mathrm{O}$ ]; and lipids (olive oil). As ant activity and walking speed positively correlate with temperature (Hurlbert et al., 2008; Jayatilaka et al., 2011), the timespan between setting the bait and attracting the highest number of ant species is shorter in environments with higher ambient temperatures than in cooler areas (Vogt et al., 2003). To determine the respective best-suited timespan at each elevational level, we observed the accumulation of ants on nutrient baits for extended periods. This timespan for plots at 1000 , $1500,2000,2500$, and $3000 \mathrm{~m}$ a.s.l. was $2,3,4,4.5$, and $5 \mathrm{~h}$, respectively. At these time points, we collected the respective baits and all ants within or at the opening of the bait tube.

All ants were identified to the morpho-species or species level. The ant fauna of Ecuador consists of at least 650 species, but it is taxonomically poorly defined (Salazar et al., 2015). Therefore, we established a mitochondrial cytochrome $c$ oxidase I (COI) barcode reference library to refine our definition of morphospecies (see also Domínguez et al., 2016). COI barcodes for the ant species were obtained in collaboration with the Biodiversity Institute of Ontario using sequencing techniques and tools in the Barcode of Life Database (BOLD; Ratnasingham and Hebert, 2007). New sequences for the study were uploaded onto the BOLD database (www.boldsystems.org/) and are available under DOI: dx.doi.org/10.5883/DS-SANFRAF, with GenBank accession numbers KY441904 to KY442061. We compared our specimens with those deposited at the Ecuadorian Ant Reference Collection (ARCE), housed in Instituto de Ciencias Biológicas of the Escuela Politécnica Nacional, and curated by D. A. Donoso. Ants identified to morphospecies bear an ARCE morpho-species number. Voucher specimens of all species and morpho-species have been deposited in the ARCE collection and the Museum at Universidad Técnica Particular de Loja.

The relative use of the nutrient baits filled with $\mathrm{NaCl}, \mathrm{CH}_{2} \mathrm{O}$, $\mathrm{CH}_{2} \mathrm{O}$-amino acid, and lipids decreased with increasing elevation (all effect sizes negative, $\mathrm{p}<0.001$ ), whereas amino acid baits and water control baits did not show a significant pattern $(p>0.05)$. 
Likewise, the morphological trait constitution of ant species was not related to the used nutrient types. As differences in nutrient preferences do not affect our subsequent analyses, we will in the following report the summary statistics of ant assemblages captured across all bait types. We used the total number of species in all 30 bait tubes as a measure of species richness within the plots during the two seasons. Several ant species demonstrate recruitment behavior to monopolize nutrient sources; this can lead to decreasing ant species richness or an overestimation of numbers of individuals after the arrival of a dominant species at a bait (Davidson, 1998). We therefore calculated the incidence of ants (instead of abundances based on sums of individuals) as the sum of the number of occurrences of each species at all baits. For example, the occurrence of one species at three baits, another species at five baits, and a further species at one bait would result in an incidence value of nine, independent of the number of individuals or the total number of occupied baits. Ant incidence therefore is a mixed measure of the occurrence, species richness, and (foraging) activity of the ant assemblage. We consequently expect a high correlation between the incidence and richness of ants. Additionally, we used a null model to test for deviations of the observed incidence-elevation relationship from a pattern expected with a random distribution of ant incidences across the elevational gradient. Differences between observed patterns and random patterns from null models indicate that ecological processes structured the observed pattern; such ecological processes include filtering from the environment (observed values are lower than null-model values; underdispersion) and competition (observed values are higher than null-model values; overdispersion). For the null model, we shuffled the incidence values of the species-incidence matrix 1000 times, while maintaining the frequencies of species incidences (fixed column sums) with the function randomizeMatrix from the add-on package picante (Kembel et al., 2010) in R (R Core Team, 2014). This null model leads to ant assemblages with random incidences across the elevational gradient. Afterwards, we calculated standardized effect sizes for the incidence of ants as ses $X=\left[X_{\text {observed }}-\operatorname{mean}\left(X_{r \text { andom }}\right)\right] / \operatorname{sd}\left(X_{\text {random }}\right)$, where $X_{\text {observed }}$ is the observed incidence of ants, mean $\left(X_{\text {random }}\right)$ is the mean of the randomizations of the null-model, and sd $\left(X_{\text {random }}\right)$ is the standard deviation of the randomly calculated ant incidence.

To analyze changes in the composition of species along the elevational gradient and with forest degradation, we conducted a detrended correspondence analysis for the combined dataset of ant incidence across both seasons. Detrended correspondence analysis eliminates the arch effect of correspondence analyses by detrending. For example, the first axis is divided into segments in which the samples are centered to have a mean of zero for the second axis, and a similar process was used for higher axes. Compression of the ends of the gradients was corrected by nonlinear rescaling, in which sample scores were shifted along each axis by an average width of one (Hill and Gauch, 1980). This procedure leads to axes that are scaled in units of species standard deviation and resembles beta diversity. We used the function decorana and fitted elevation and forest degradation onto the ordination using the function envfit with 999 permutations. Both functions are implemented in the add-on package vegan (Oksanen et al., 2016).

\subsection{Calculation of functional richness of ant assemblages}

To calculate the functional richness of ant assemblages, we used continuous measures of four morphological traits that are related to predatory behavior (Yates et al., 2014 and references within): Weber's length (a proxy for the overall size), head length (indicative of diet), mandible length (longer mandibles allow larger prey), and length of the hind femur (linked to foraging speed). We measured these traits on 1-5 individuals per species depending on the number of individuals available and calculated the mean value per species. We could not obtain trait measures for the mandible length of 11 ant species because mandibles of the specimen were not intact or measurements were not possible; this constituted $12 \%$ of the total number of ant incidences: genus Camponotus ( 1 species), Myrmelachista (2 species), Nylanderia (1 species), Pheidole (2 species), and Solenopsis (5 species). For these species, we used the mean trait value of the genus. Furthermore, we excluded the species Pseudomyrmex termitarius (contributing altogether five incidences on two plots) from the calculation of functional richness as we could not obtain trait data for the species, and it was the only representative of its genus. To achieve normal distribution, we $\log _{10}$-transformed all trait variables before statistical analysis. Furthermore, we corrected for covariance of body part measures and overall body size (Stern and Emlen, 1999) by using residuals of linear regressions against the Weber's length as response variables (Gibb and Parr, 2013; Kaspari and Weiser, 1999). Pearson product-moment correlation coefficients (PPMC) between the four morphological ant traits Weber's length, head length, mandible length, and hind femur length were always $<0.40$. We calculated the (raw) functional richness (FRic) of ant assemblages as a measure of the volume of a convex hull around all species of an assemblage projected onto a multidimensional trait space using principal coordinates analysis (PCoA) based on the Euclidean distances between species traits (Villéger et al., 2008) and the function dbFD from the add-on package FD (Laliberté and Legendre, 2010) in R (R Core Team, 2014). We standardized FRic by dividing the FRic values by the maximum possible FRic value of a fictitious ant assemblage consisting of all recorded ant species. The standardized FRic values could therefore range between 0 (plot without any ant species) and 1 (plot with all possible species). We achieved similar results when we used a Hutchinsonian hypervolume approach to calculate functional richness (Blonder et al., 2014). For simplicity, we will not report the results of the hypervolume approach. To test whether the raw FRic values differed from values expected under a random trait distribution, we calculated the standardized effect sizes of FRic (ses FRic) using the same approach as for the incidence of ants, by randomizing the rows of the species-traits matrix 1000 times, while keeping the trait combinations fixed (random trait combinations are biologically not meaningful).

\subsection{Predation rate on artificial caterpillars}

To quantify predation rates (attacks by natural enemies) on herbivorous arthropods, we used 300 artificial caterpillars within each study plot. We exposed the artificial caterpillars on 30 randomly selected plants in the shrub layer $(0.5-2.0 \mathrm{~m}$ above ground; low damage by herbivores) of each plot by pinning 10 artificial caterpillars with a thin wire onto the surface of 10 leaves of each plant. Artificial caterpillars consisted of green-colored (to mimic palatable and undefended prey; see Howe et al., 2009), oil-based, and nontoxic plasticine (STAEDTLER ${ }^{\circledR}$ Noris Club 8421). We pressed the plasticine through a syringe to ensure comparable shape and thickness ( $20 \mathrm{~mm}$ long and $2-3 \mathrm{~mm}$ in diameter), as well as a smooth surface. After five days, we recollected all artificial caterpillars; 467 (2.9\%) of the exposed artificial caterpillars fell to the ground or could not be recovered and were excluded from the analysis. All recovered artificial caterpillars were directly inspected for bite marks, which were assigned to predator groups (ants, bees and wasps, birds, others) using the bite-mark catalogue of Low et al. (2014). If bite marks were not directly identifiable, we examined them more carefully in the lab using a magnifying lens. As we could not differentiate bite marks from one or more predation events and made by one or several predator individuals, we assessed predation qualitatively instead of quantitatively, i.e., predated/not predated. As ants were by far the most abundant predators of artificial caterpil- 
lars across the studied gradient ( $>70 \%)$, we only used ant predation events in our analyses and calculated predation as the percentage of artificial caterpillars with bite marks made by ants.

\subsection{Path analyses}

We conducted two separate path models for ant incidence and richness due to high multicollinearity between both measures $\left(r^{2}=0.9\right.$; PPMC; Tu et al., 2005). Due to the nested structure of our data and because of the binomial distribution of the predation data, we tested the path models after Shipley's directional separation method (Shipley, 2009) within the $\mathrm{R}$ environment ( $\mathrm{R}$ Core Team, 2014). We conducted the confirmatory path analysis using three mixed effect regressions to test the initially assumed direct and indirect effects of abiotic factors (elevation as proxy for temperature, season, and degradation) on ant incidence (respectively species richness), ant functional richness, and predation of artificial caterpillars by ants. To account for the nested structure of our data (sampling of wetter and drier season nested in plot), we included study plot as a random effect in all models to correct for pseudo replication. To allow for comparison of the path model coefficients of the fixed effects, we z-transformed all predictor variables in the three regressions and the response variables from regression one and two. These first two regressions included the effects of elevation, season, and forest degradation on the incidence of ant species (respectively species richness) and raw functional richness. To account for the potential relationship between the incidence of ants (respectively species richness) and functional richness, we included species incidence in the second regression. To test the conditional independence of nested data, we used linear mixed effect models with normal error distribution (LMER; function lmer in the add-on package lme4; Bates et al., 2015) and fitted the LMERs using restricted maximum-likelihood estimation (REML). The third regression included the effects of elevation, season, forest degradation, ant incidence (respectively species richness), and ant functional richness on the predation of artificial caterpillars. In addition, we included a random factor for each observation event to remove overdispersion (Harrison, 2014). In this case, we used a generalized linear mixed effect model with binomial error distribution (GLMER; function glmer in the add-on package lme4; Bates et al., 2015) and fitted the model using a maximum-likelihood estimation (Laplace approximation). We derived the P-values from $z$-tests of estimated model coefficients using the function cftest from the add-on package multcomp (Hothorn et al., 2008). We applied dseparation to test each hypothesized conditional independency separately using the LMERs and GLMER to obtain the probability that the partial slope of the dependent variable was significantly different from zero. We combined and tested the probabilities of all independence claims using $C$ statistics (Shipley, 2009).

In a next step, we compared the performance of both path models (ant incidence and richness) by performing bootstrap analysis of regression models two (functional richness) and three (predation). To do so, we ran these two regressions of both path models based on 1000 bootstrap samples of the original data. Then, we compared the AIC values of the bootstrap regressions between the path model of ant incidence and richness using t-statistics. This comparison revealed no significant differences between the performance of regressions of incidence and species richness (all $\mathrm{p}>0.9$; Welch's $t$-test). To facilitate the readability, we will in the following report the results using ant incidence only, but emphasize that they apply equally for species richness. We included results of the model of species richness in the Supplementary material.
Table 1

Distribution of ant individuals, incidence (a combined measure of ant occurrence and activity; for details, see Methods section), and species richness during the wetter season and drier season and on natural plots and degraded plots.

\begin{tabular}{lllll}
\hline Season & Plot type & Individuals & $\begin{array}{l}\text { Ant } \\
\text { incidence }\end{array}$ & $\begin{array}{l}\text { Species } \\
\text { richness }\end{array}$ \\
\hline Wetter season & Natural & 1002 & 137 & 44 \\
& Degraded & 1034 & 141 & 46 \\
Drier season & Natural & 1610 & 208 & 51 \\
& Degraded & 1264 & 205 & 52 \\
\hline
\end{tabular}

Table 2

Changes in ant incidence (a combined measure of ant occurrence and activity, for details, see Methods section; model 1), (raw) functional richness of ant assemblages (model 2), and predation of artificial caterpillars (model 3) with elevation, drier vs. wetter season, and forest degradation. Linear mixed effect models were used for models 1 , and 2, and a generalized linear mixed effect model was used for model 3. Study plots were included as random effect in models 1-3 to correct for pseudoreplication; model 3 included each observation as a random effect to remove overdispersion. Boldface indicates significant values. Results equally apply for species richness, see Supplementary material A.2.

\begin{tabular}{lrcc}
\hline Source of variation & Estimate & z-value & $p$-value \\
\hline Model 1: Ant incidence & & & \\
Elevation & $-7.2 \times 10^{-1}$ & -7.2 & $\mathbf{< 0 . 0 0 1}$ \\
Season & $2.5 \times 10^{-1}$ & 2.9 & $\mathbf{< . 0 1}$ \\
Degradation & $-7.1 \times 10^{-3}$ & -0.071 & 0.94 \\
Model 2: Functional richness & & & \\
Elevation & $-3.2 \times 10^{-1}$ & 0.14 & $\mathbf{0 . 0 1 7}$ \\
Season & $8.9 \times 10^{-2}$ & 0.96 & 0.34 \\
Degradation & $-4.7 \times 10^{-2}$ & -0.53 & 0.34 \\
Ant incidence & $5.8 \times 10^{-1}$ & 4.6 & $<\mathbf{0 . 0 0 1}$ \\
& & & \\
Model 3: Predation of artificial caterpillars & & \\
Elevation & $-8.5 \times 10^{-2}$ & -0.41 & 0.69 \\
Season & $-5.3 \times 10^{-1}$ & -3.7 & $<\mathbf{0 . 0 0 1}$ \\
Degradation & $1.1 \times 10^{-1}$ & 0.87 & 0.38 \\
Ant incidence & $6.2 \times 10^{-1}$ & 2.7 & $<\mathbf{0 . 0 1}$ \\
Functional richness & $2.2 \times 10^{-2}$ & 0.099 & 0.92
\end{tabular}

\section{Results}

\subsection{Ant incidence}

In total, we recorded 4910 ant individuals across the 27 study plots. The sum of ant incidences at all baits was 691 ; the number of species at the same bait ranged from 0 to 4 . We used ant incidence as a combined measure of the overall richness, occurrence, and (foraging) activity of ant species on the plots; we defined ant incidence as the sum of all species occurrences across 30 baits. Ant incidence was highly correlated with species richness $\left(r^{2}=0.90, p<0.001\right.$; PPMC). The sampled individuals belonged to 87 ant species, which could be divided into 9 species and 78 morpho-species, from 5 subfamilies (Dolichoderinae, Formicinae, Myrmicinae, Ponerinae, and Pseudomyrmicinae) and 14 genera. The number of ant individuals, incidences, and species differed between seasons, but the number in natural forests was similar to that in degraded forests (Table 1). The observed ant incidence and also the standardized effect size of ant incidence decreased with elevation (Table 2, Fig. 1A). Ant incidence was higher in the drier season than in the wetter season, and forest degradation had no significant effect (Table 2, Figs. 1A and 2). Species richness showed a pattern similar to ant incidence (Supplementary material A.2). The first decorana axis was strongly and positively correlated with elevation $\left(\mathrm{r}^{2}=0.92, \mathrm{p}<0.001\right.$; PPMC), but not with degradation $\left(r^{2}=0.0089, p=0.72\right.$; PPMC; for decorana visualization, see Supplementary material A.1). 

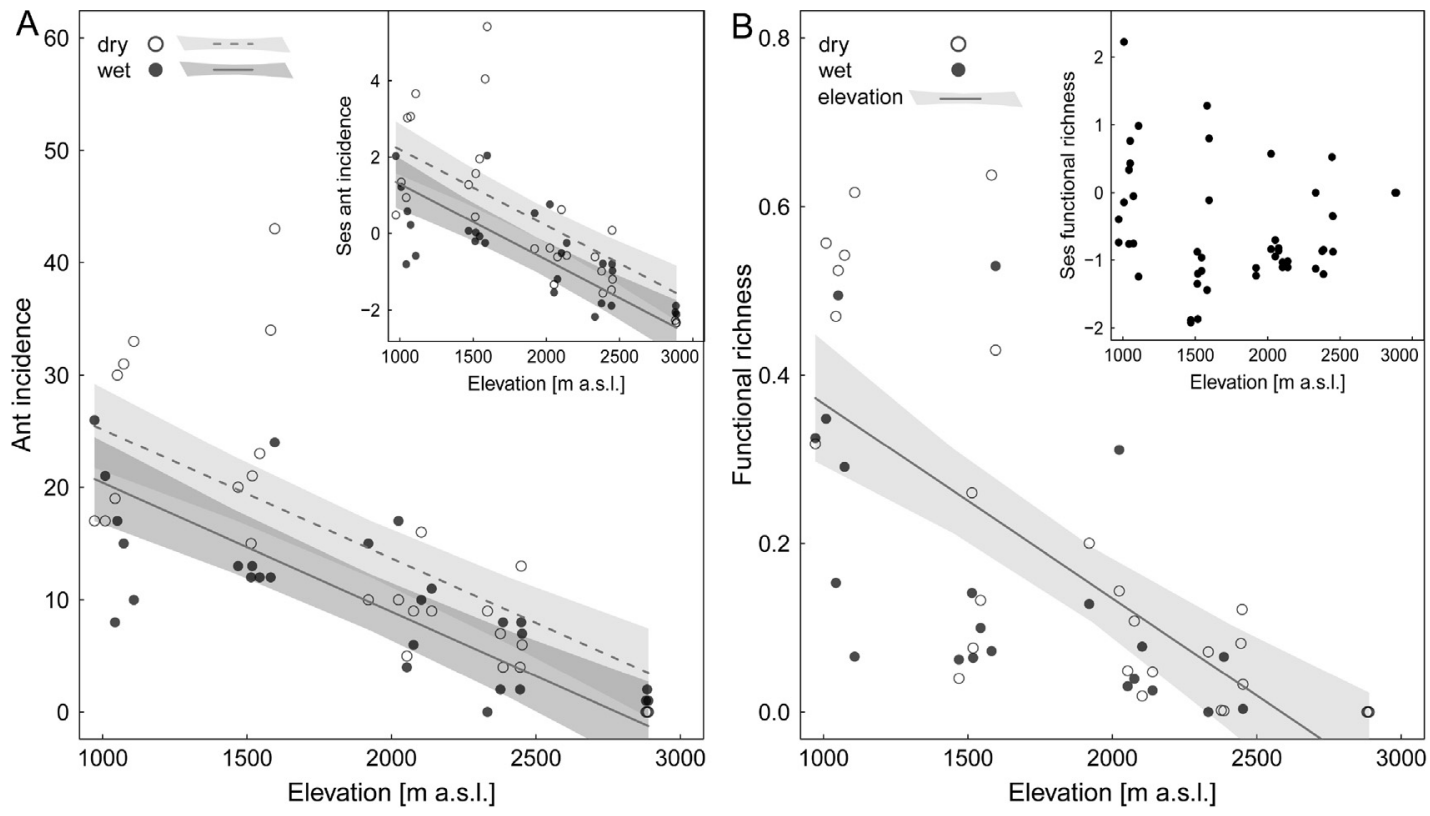

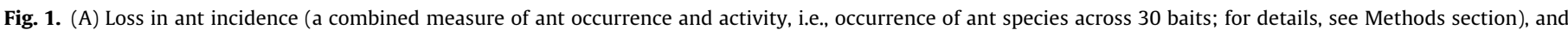

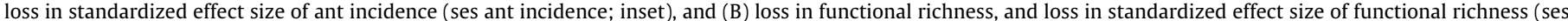

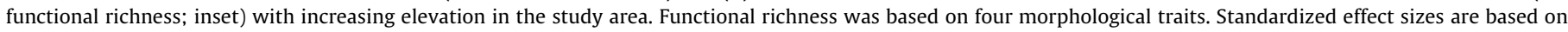

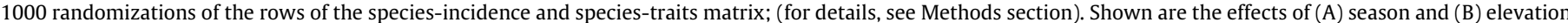

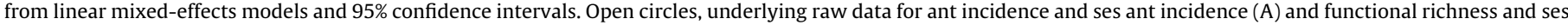
functional richness (B) in the drier season; filled circles, that in the wetter season.

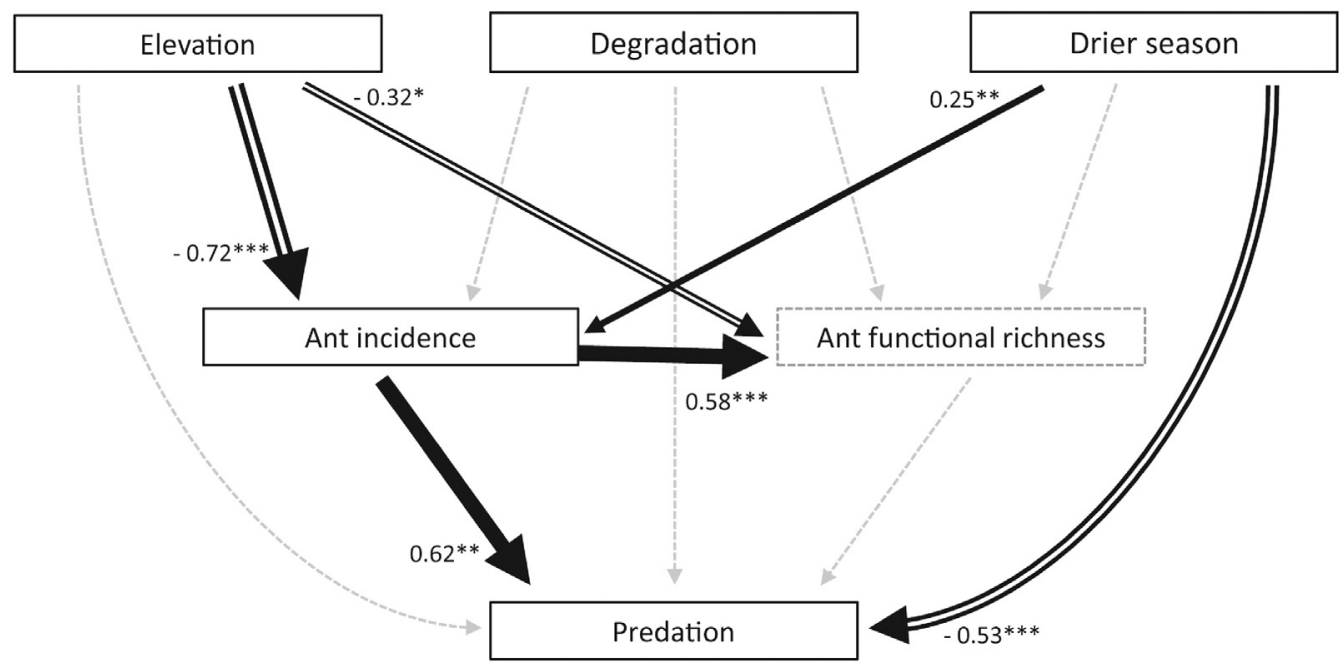

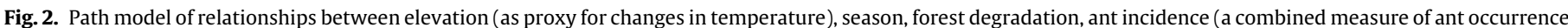

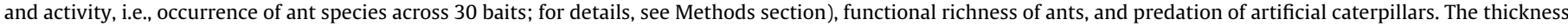

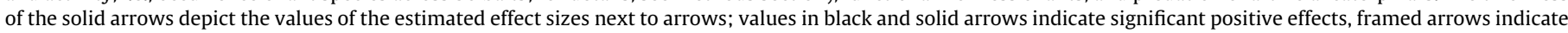

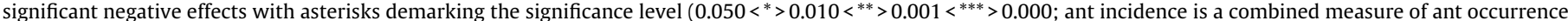

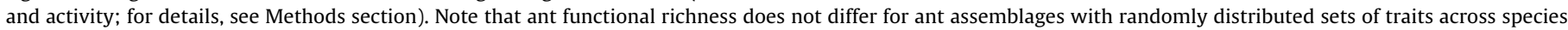
(indicated by dashed frame; cf. Fig. 1B; for details, see Methods and Results section). Results equally apply for species richness, see Supplementary material A.3.

\subsection{Functional richness}

The functional richness calculated from the four ant morphological traits (Weber's length, head length, mandible length, and hind femur length) ranged from 0.0 to $0.64(0.18 \pm 0.20$; mean $\pm S D)$. The (raw) functional richness decreased with elevation and was most strongly and positively affected by ant incidence (Table 2, Figs. 1B and 2) and species richness (Supplementary material A.2). Neither forest degradation nor season influenced the functional richness of the sampled ant assemblage (Table 2). Yet, the relationship between functional richness and elevation became insignificant when using standardized effect sizes instead of raw values, which indicated that the pattern of the (raw) functional richness does not differ from a pattern expected for ant assemblages with randomly distributed sets of traits across species (Fig. 1B).

\subsection{Predation rate}

In total, we identified 2119 bite marks on 15,733 collected artificial caterpillars. Most of the bite marks originated from ants (1540 marks; 73\%), followed by wasps and bees (201 marks; 9.5\%), birds (133 marks; 6.3\%), and unknown predators (245 marks; $12 \%$ ). 
The predation rate of ants on artificial caterpillars across 5 days ranged from 0.0 to $0.36(0.099 \pm 0.081$; mean $\pm S D)$. In general, predation rates decreased with increasing elevation (estimate elevation $=-4.9^{*} 10^{-5}, \mathrm{p}=0.0057, \mathrm{r}^{2}=0.14$ ), but the effect of elevation on the predation rate of artificial caterpillars was caused by ant incidence (Table 2, Fig. 2). Ant incidence and species richness affected predation rate on artificial caterpillars positively, whereas drier season had a direct negative effect on the predation rate, but an additional indirect positive effect caused by ant incidence (Table 2 , Fig. 2). Forest degradation neither influenced any aspect of ant assemblages nor the predation of artificial caterpillars (Table 2). Replacing ant incidence by species richness within the same path model yielded similar patterns of the main pathways (Supplementary material A.2, A.3). The result of the $\mathrm{Chi}^{2}$-test for independence supported the assumptions of both path models (path model with ant incidence: $\mathrm{X}^{2}=6.3$; $\mathrm{df}=12$; P-value $=0.90$; path model with species richness: $\mathrm{X}^{2}=5.9 ; \mathrm{df}=12 ; \mathrm{P}$-value $=0.92$ ).

\section{Discussion}

Ant incidence was highly correlated with species richness without significant differences in reaction to abiotic factors and as predictors of functional richness and predation. Incidence and richness of ants declined with elevation and increasing rainfall (wetter vs. drier season), whereas forest degradation did not affect both measures. Functional richness was mainly driven by the incidence (respectively richness) of ants. The predation rate on artificial caterpillars decreased along the elevational gradient. Most importantly, ant incidence (respectively richness) and season directly affected the predation rate on artificial caterpillars, whereas elevation and raw functional richness did not have direct effects on the predation rates.

\subsection{Ants as indicators of responses to environmental changes}

We quantified ant incidences, i.e., a measure of the occurrence and (foraging) activity of ants, by using an easily implementable approach based on baits with six different nutrient types. The observed ant incidence (as well as the standardized effect sizes) and richness clearly decreased along the elevational gradient, which was even more pronounced as the time of exposure of the baits was increased with increasing elevation. Furthermore, the community composition of ants markedly changed with elevation, which indicated a high species turnover along the elevational gradient (Bishop et al., 2014; Longino et al., 2014; Nowrouzi et al., 2016). Temperature is one of the most important abiotic predictors of the decline in ant species with elevation as it limits the activity of ants and thus the access to resources (Sanders et al., 2007; but also see Kaspari et al., 2000). Season was an abiotic factor that also influenced the incidence and species richness of ants, with higher ant incidence during the drier season. This typical finding (Basu, 1997; El Keroumi et al., 2012; but also see Castro et al., 2012) might be attributed to higher foraging activity at higher temperatures (Medeiros et al., 2014), seasonal changes in the brood cycle, or availability of nest sites or food (Levings, 1983). However, in our study, higher ant activity did not seem to translate into higher predation in the herbal and shrub layers, but might be instead limited to ground-foraging activity (see subsection 4.3). The main driver of the raw functional richness was the incidence of ants. As ant incidence was highly correlated with species richness $\left(r^{2}=0.90, p<0.001\right)$ and species-rich assemblages are likely to comprise more diverse functional traits, habitats with high ant incidence will also have higher functional richness (Cadotte et al., 2011). The raw functional richness of ant assemblages also decreased with elevation, which we confirmed by using a Hutchinsonian hypervolume approach (data not shown;
Blonder et al., 2014). Reymond et al. (2013), who found a similar pattern in the Swiss National Park, explained this finding with the filtering effect of the environment in which only species with traits adapted to harsh environmental conditions at high elevations can tolerate the habitat (also see, e.g., Machac et al., 2011). However, our finding of no elevation pattern for the standardized effect sizes indicates that the raw functional richness is mainly driven by declining ant incidence respectively richness and is not actually a filtering effect of the environment; this suggests that the measured functional traits are independent from elevation.

When we consider ants as indicators of responses to environmental changes, it should be stressed that the effects of global warming are already noticeable in the study area. Meteorological stations within and near the study area have evidenced a significant warming of at least $0.6^{\circ} \mathrm{C}$ within the last 45 years of $1961-2008$ (Bendix et al., 2010; Peters et al., 2013), and future projections of the Intergovernmental Panel on Climate Change (IPCC) point to a further warming of the study area of around $+4{ }^{\circ} \mathrm{C}$ by 2100 , with the assumption that greenhouse gas concentrations will be high in 2100 (936 $\mathrm{ppm} \mathrm{CO}_{2}$ and high radiative forcing of $8.5 \mathrm{~W} / \mathrm{m}^{2}$; RCP8.5scenario; Meinshausen et al., 2011). A temperature increase of $+4^{\circ} \mathrm{C}$ by 2100 at the actual average lapse rate in the study area of $-0.52{ }^{\circ} \mathrm{C}$ per $100 \mathrm{~m}$ (Bendix et al., 2008a,b) would predict an elevational shift of the pattern of ant incidence and richness of approximately $80 \mathrm{~m}$ per decade. Based on the results reported here and assuming a one-dimensional relationship between temperature and species richness, we would expect an approximately 1.3- to 4-fold increase in species richness by 2080 (from 38 to 51 species at $1500 \mathrm{~m}$ a.s.l., from 23 to 38 species at $2000 \mathrm{~m}$ a.s.l., from 12 to 23 species at $2500 \mathrm{~m}$ a.s.l., and from 3 to 12 species at $3000 \mathrm{~m}$ a.s.l.). However, interrelationships among changes in temperature, seasonal patterns of precipitation, and species interactions are complex and difficult to predict. Our finding of opposing effects of drier season on ants and the predation process supports this assumption. In addition, predictions of changes in species distributions based on changes in abiotic conditions usually do not consider, e.g., whether the ability of a species to disperse will keep pace with the increasing temperature or how competition between species will influence species composition (Chapin III et al., 2000). Therefore, projections can be made only with reservations (Colwell et al., 2008; Lavergne et al., 2010).

\subsection{Ants as indicators of forest degradation}

In contrast to findings of several other studies (e.g., Philpott et al., 2010 and references within; for a review see Underwood and Fisher, 2006), forest degradation in our study area did not have an effect on the incidence, richness, and raw functional richness of ant assemblages, or on assemblage composition. Habitat degradation mainly affects ant assemblages through changes in local factors, such as abiotic changes in soil and microclimatic conditions, including moisture, temperature, and exposure (Philpott et al., 2010). Our results match findings of Donoso et al. (2017), who report no change in litter ant community composition after 15 years of continuous monitoring in a secondary cloud forest in northern Ecuador. Furthermore, low impact land use, such as traditional crop and pasture systems may sometimes lead to an increase of ant abundances (Folgarait, 1998). However, other analyses indicate that the composition of traits, functional groups, or occurrence of specialized ants might change, even if numbers of ants do not change (Fotso Kuate et al., 2015; Hoffmann and Andersen, 2003; Leal et al., 2012; Peters et al., 2014). Two reasons may explain our results: On the one hand, our findings suggest that the present forest degradation of the abiotic and biotic conditions in our study area might not be severe enough to negatively affect the ground-foraging ant assemblages in degraded forests or that the ant assemblages man- 
aged to recover: Ant assemblages are able to reach levels of species richness and species compositions similar to that of natural forests after several decades of even acute degradation events in the past (Ryder Wilkie et al., 2009; but also see Bihn et al., 2008). Also, a high connectivity of the matrix habitat that connects the degraded and natural forests in our study area may have contributed to similar ant assemblages in degraded and natural forest plots (Harrison and Bruna, 1999; Hunter, 2002; Schoereder et al., 2004). Moreover, all degraded forest plots were in close proximity to forest edges. Edge effects might have induced an increase of the depth and quality of the leaf litter (compared to the interior of degraded forests), making the litter more similar to the litter in natural forests (Philpott et al., 2010). However, we cannot finally determine the principal reason for the absence of a degradation effect on the epigaeic ant assemblages, as we do not have data on the degradation history, age, matrix connectivity, and litter quality of the degraded forest plots. On the other hand, our baiting method used might also have contributed to our results. It is thought that nutrient baits mostly attract generalist ant species. As specialized ant species are assumed to react more strongly to changes in habitat quality, we might have missed the more sensitive portion of the ant assemblage. Additionally, our baiting approach collected ants from ground-dwelling assemblages and canopy-dwelling ants may react differently and more strongly towards degradation (Floren et al., 2002; Klimes et al., 2015; Yanoviak and Kaspari, 2000).

\subsection{Ants as indicators of predation}

We quantified predation based on ant bite marks on artificial caterpillars that can be easily integrated in the practice of ecosystem management. Even though attack rates on artificial caterpillars of different materials might differ (Sam et al., 2015b), an increasing number of studies use model caterpillars as surrogates for predation rates on real caterpillars (Low et al., 2016; Meyer et al., 2015 and references within). Almost three-quarters (73\%) of the observed attack marks in our study originated from ants, which supports the importance of ants as a major group of predators of herbivorous arthropods in rainforests (Seifert et al., 2016). Predation of artificial caterpillars decreased with increasing elevation, which reflects the pattern of ant incidence and richness and supports the findings of Sam et al. (2015a). Surprisingly, the predation of artificial caterpillars was significantly higher in the wetter season than in the drier season, which contrasts the pattern of higher ant incidence (respectively richness) during the drier season. This finding could be explained by the positive relationship between resource availability and foraging activity of ants (Medeiros et al., 2014; but also see Raimundo et al., 2009). For instance, a peak of predation rates on artificial caterpillars during the wetter season has also been found in sub-montane forests in Uganda (Molleman et al., 2016). The authors explained the predation maximum with the simultaneous peak in prey density, which would lead to responses of the foraging or breeding activity of the predators. However, Brehm (2002) found no marked seasonal changes of moth communities in our study area. Lower predation of artificial caterpillars during the drier season but a simultaneously high incidence of ants would therefore suggest a shift of the ants foraging activity from the foliage layer to more abundant resources, e.g., in the leaf litter, but further studies are needed to test this assumption.

Elevation, forest degradation, or the raw functional richness of ants did not explain the variation in predation of artificial caterpillars. We expected that the functional richness of ant assemblages was related to predatory behavior; therefore, we in turn expected that ant functional richness would be more strongly related to predation rates than the overall incidence or species richness of ants. Yet, the functional traits measured (Weber's length, and length of head, mandible, and hind femur) might not be ecologically linked to the rate of predation events. Alternatively, as we used only one type of artificial caterpillar, which did not move or emit visual or chemical cues used by predators to locate their prey, possibly only one type of predatory ant was attracted, which would also make the functional richness measure irrelevant. However, predation experiments comparing attack rates on live and artificial caterpillars made of either dough or plasticine revealed no significant differences (Sam et al., 2015b). Nevertheless, Sam et al. (2015b) did not test whether their single type of caterpillar prey, although one of the most common species in the understory, attracted a representative portion of all possible predators of the diverse group of herbivorous arthropods. Even though we cannot completely eliminate these methodological doubts, our finding of no association between functional richness and predation underlines that the occurrence, richness, and activity of species are more important drivers of ecosystem processes than their functional measures (Stuart-Smith et al., 2013).

\section{Conclusions}

Our findings highlight the applicability of simple monitoring tools for studying ant assemblages and related predation rates. We found that incidence of ants as a measure of ant occurrence and activity, as well as species richness can be used as suitable indicators of responses to rising temperatures and of predation, but not of forest degradation within complex rainforest ecosystems. Rising temperatures might favor more abundant, species-rich, and active ant assemblages and therefore higher predation rates in montane forests at higher elevations if dispersal of ants keeps pace with the climatic changes. However, projections can only be made with reservations, as other species interactions e.g. between herbivores and plants will additionally affect the responses of the same food web, which is of much higher complexity. Our finding that forest degradation did not affect any of the studied biotic aspects proposes lightly degraded forests as suitable habitat for functional epigaeic ant assemblages. Thereby, our results suggest that the occurrence, richness, and activity of functional taxa might be more important for the functioning of related ecosystem processes than their functional measures. Our findings also suggest that the incidence and species richness of ants are suitable indicators of changes in abiotic conditions and are also functional indicators of an important ecosystem process. Hence, simple measures such as ant incidence and species richness can supersede the use of more labor-intensive, trait-based measures for quantifying the functionality of ecosystems.

\section{Acknowledgements}

We thank the Ministerio del Ambiente de Ecuador for granting research permits and Nature and Culture International for providing the research station. We thank the assistants Claudia Frank, Leonie Greiner, Isabel Killian, Esther-Marie Lintzel, Julian Mattes, Annika Niepoth, Isabel Pérez Postigo, and Stefan Wallney, who were involved in the collection of data. This work was supported by the Deutsche Forschungsgemeinschaft within the research unit PAK823-825 under BE1780/34-1, BR1293/11, FA925/7-1, HO3296/4-1, ZI698/8-1 (subproject C2). We thank the two anonymous reviewers for their valuable and constructive comments on the manuscript and Karen A. Brune for linguistic revision of the manuscript. 


\section{Appendix A. Supplementary data}

Supplementary data associated with this article can be found, in the online version, at http://dx.doi.org/10.1016/j.ecolind.2017. 01.029.

\section{References}

Andersen, A.N., Majer, J.D., 2004. Ants show the way down under: invertebrates as bioindicators in land management. Front. Ecol. Environ. 2, 291-298, http://dx. doi.org/10.1890/1540-9295(2004)002[0292:ASTWDU]2.0.CO;2.

Andersen, A., 1986. Diversity, seasonality and community organization of ants at adjacent heath and woodland sites in Southeastern Australia. Aust. J. Zool. 34, 53-64, http://dx.doi.org/10.1071/ZO9860053.

Andersen, A., 1997. Functional groups and patterns of organization in North American ant communities: a comparison with Australia. J. Biogeogr. 24, 433-460, http://dx.doi.org/10.1111/j.1365-2699.1997.00137.x.

Bartholomew, G.A., Lighton, J.R.B., Feener, D.H.J., 1988. Energetics of trail running, load carriage, and emigration in the column-raiding army ant Eciton hamatum. Physiol. Zool. 61, 57-68.

Basu, P., 1997. Seasonal and spatial patterns in ground foraging ants in a rain rorest in the Western Ghats. India Biotropica 29, 489-500, http://dx.doi.org/10.1111/ j.1744-7429.1997.tb00043.x.

Bates, D., Mächler, M., Bolker, B., Walker, S., 2015. Fitting linear mixed-effects models using lme4. J. Stat. Softw. 67, 1-48, http://dx.doi.org/10.18637/jss. v067.i01.

Bendix, J., Rollenbeck, R., Fabian, P., Emck, P., Richter, M., Beck, E., 2008a. Climate variability. In: Beck, E., Bendix, J., Kottke, I., Makeschin, F., Mosandl, R. (Eds.), Ecological Studies, Vol 198: Gradients in a Tropical Mountain Ecosystem of Ecuador. Springer, Berlin Heidelberg, pp. 281-290, http://dx.doi.org/10.1007/ 978-3-540-73526-7_27.

Bendix, J., Rollenbeck, R., Richter, M., Fabian, P., Emck, P., 2008b. Climate. In: Beck, E., Bendix, J., Kottke, I., Makeschin, F., Mosandl, R. (Eds.), Ecological Studies, Vo 198: Gradients in a Tropical Mountain Ecosystem of Ecuador. Springer, Berlin Heidelberg, pp. 63-73, http://dx.doi.org/10.1007/978-3-540-73526-7_8.

Bendix, J., Behling, H., Peters, T., Richter, M., Beck, E., 2010. Functional biodiversity and climate change along an altitudinal gradient in a tropical mountain rainforest. In: Tscharntke, T., Leuschner, C., Veldkamp, E., Faust, H., Guhardja, E., Bidin, A. (Eds.), Tropical Rainforests and Agroforests Under Global Change, Environmental Science and Engineering. Springer Berlin Heidelberg, Berlin, Heidelberg, pp. 239-268, http://dx.doi.org/10.1007/978-3-642-00493-3_11.

Bihn, J.H., Verhaagh, M., Brändle, M., Brandl, R., 2008. Do secondary forests act as refuges for old growth forest animals? Recovery of ant diversity in the Atlantic forest of Brazil. Biol. Conserv. 141, 733-743, http://dx.doi.org/10.1016/j.biocon. 2007.12.028.

Bihn, J.H., Gebauer, G., Brandl, R., 2010. Loss of functional diversity of ant assemblages in secondary tropical forests. Ecology 91, 782-792, http://dx.doi. org/10.1890/08-1276.1.

Bishop, T.R., Robertson, M.P., van Rensburg, B.J., Parr, C.L., 2014. Elevation-diversity patterns through space and time: ant communities of the Maloti-Drakensberg Mountains of southern Africa. J. Biogeogr. 41, 2256-2268, http://dx.doi.org/10 1111 /jbi.12368.

Blois, J.L., Williams, J.W., Fitzpatrick, M.C., Jackson, S.T., Ferrier, S., 2013. Space can substitute for time in predicting climate-change effects on biodiversity. Proc. Natl. Acad. Sci. U. S. A. 110, 9374-9379, http://dx.doi.org/10.1073/pnas. 1220228110.

Blonder, B., Lamanna, C., Violle, C., Enquist, B.J., 2014. The $\mathrm{n}$-dimensional hypervolume. Glob. Ecol. Biogeogr. 23, 595-609, http://dx.doi.org/10.1111/ geb.12146.

Brehm, G., 2002. Diversity of geometrid moths in a montane rainforest in Ecuador PhD-thesis. Universität Bayreuth.

Cadotte, M.W., Carscadden, K., Mirotchnick, N., 2011. Beyond species: functiona diversity and the maintenance of ecological processes and services. J. Appl. Ecol. 48, 1079-1087, http://dx.doi.org/10.1111/j.1365-2664.2011.02048.x.

Cardinale, B.J., Duffy, J.E., Gonzalez, A., Hooper, D.U., Perrings, C., Venail, P. Narwani, A., Mace, G.M., Tilman, D., Wardle, D.A., Kinzig, A.P., Daily, G.C. Loreau, M., Grace, J.B., Larigauderie, A., Srivastava, D.S., Naeem, S., 2012. Biodiversity loss and its impact on humanity. Nature 486, 59-67, http://dx.doi org/10.1038/nature11148.

Carignan, V., Villard, M.-A., 2002. Selecting indicator species to monitor ecological integrity: a review. Environ. Monit. Assess. 78, 45-61, http://dx.doi.org/10. 1023/A:1016136723584.

Castro, F.S., Gontijo, de, Castro, A.B., Ribeiro, P.D.T.A., 2012. Annual and seasonal changes in the structure of litter-dwelling ant assemblages (Hymenoptera: Formicidae) in Atlantic semideciduous forests. Psyche (Stuttg.) 2012, 1-12, http://dx.doi.org/10.1155/2012/959715.

Chapin III, F.S., Walker, B.H., Hobbs, R.J., Hooper, D.U., Lawton, J.H., Sala, O.E. Tilman, D., 1997. Biotic control over the functioning of ecosystems. Science 277, 500-504, http://dx.doi.org/10.1126/science.277.5325.500.

Chapin III, F.S., Zavaleta, E.S., Eviner, V.T., Naylor, R.L., Vitousek, P.M., Reynolds, H.L., Hooper, D.U., Lavorel, S., Sala, O.E., Hobbie, S.E., Mack, M.C., Díaz, S., 2000. Consequences of changing biodiversity. Nature 405, 234-242, http://dx.doi. org/10.1038/35012241.
Colwell, R.K., Brehm, G., Cardelus, C.L., Gilman, A.C., Longino, J.T., 2008. Global warming, elevational range shifts, and lowland biotic attrition in the wet tropics. Science 322, 258-261, http://dx.doi.org/10.1126/science.1162547.

R Core Team, 2014. R: A Language and Environment for Statistical Computing. R Foundation for Statistical Computing, Vienna, Austria.

Curatola Fernández, G., Obermeier, W., Gerique, A., Sandoval, M., Lehnert, L., Thies, B., Bendix, J., 2015. Land cover change in the Andes of southern Ecuador-patterns and drivers. Remote Sens. 7, 2509-2542, http://dx.doi.org/ $10.3390 /$ rs 70302509.

Dale, V.H., Beyeler, S.C., 2001. Challenges in the development and use of ecological indicators. Ecol. Indic. 1, 3-10, http://dx.doi.org/10.1016/S1470160X(01)00003-6.

Davidson, D.W., 1977. Foraging ecology and community organization in desert seed-eating ants. Ecology 58, 725-737.

Davidson, D.W., 1998. Resource discovery versus resource domination in ants: a functional mechanism for breaking the trade-off. Ecol. Entomol. 23, 484-490, http://dx.doi.org/10.1046/j.1365-2311.1998.00145.x.

De Ruiter, P.C., Neutel, A.M., Moore, J.C., 1995. Energetics, patterns of interaction strengths, and stability in real ecosystems. Science $269,1257-1260$, http://dx doi.org/10.1126/science.269.5228.1257.

Del Toro, I., Silva, R.R., Ellison, A.M., 2015. Predicted impacts of climatic change on ant functional diversity and distributions in eastern North American forests. Divers. Distrib. 21, 781-791, http://dx.doi.org/10.1111/ddi.12331.

Delsinne, T., Arias-Penna, T., Leponce, M., 2013. Effect of rainfall exclusion on ant assemblages in montane rainforests of Ecuador. Basic Appl. Ecol. 14, 357-365, http://dx.doi.org/10.1016/j.baae.2013.04.002.

Domínguez, D.F., Bustamante, M., Albuja, R., Castro, A., Lattke, J.E., Donoso, D.A., 2016. COI barcodes for ants (Hymenoptera: Formicidae) of drylands in the south of Ecuador. Ecosistemas 25, 76-78, http://dx.doi.org/10.7818/ECOS 2016.25-2.09.

Donoso, D.A., Ramón, G., 2009. Composition of a high diversity leaf litter ant community (Hymenoptera: Formicidae) from an Ecuadorian pre-montane rainforest. Ann. Soc. Entomol. France 45, 487-499, http://dx.doi.org/10.1080/ 00379271.2009.10697631.

Donoso, D.A., 2017. Tropical ant communities are in long-term equilibrium. Ecol. Indic. 83, 515-523, http://dx.doi.org/10.1016/j.ecolind.2017.03.022.

El Keroumi, A., Naamani, K., Soummane, H., Dahbi, A., 2012. Seasonal dynamics of ant community structure in the Moroccan Argan Forest. J. Insect Sci. 12, 1-19, http://dx.doi.org/10.1673/031.012.9401.

Floren, A., Biun, A., Linsenmair, E., 2002. Arboreal ants as key predators in tropical lowland rainforest trees. Oecologia 131, 137-144, http://dx.doi.org/10.1007/ s00442-002-0874-7.

Foley, J.A., DeFries, R., Asner, G.P., Barford, C., Bonan, G., Carpenter, S.R., Chapin, F.S. Coe, M.T., Daily, G.C., Gibbs, H.K., Helkowski, J.H., Holloway, T., Howard, E.A., Kucharik, C.J., Monfreda, C., Patz, J.A., Prentice, I.C., Ramankutty, N., Snyder, P.K., 2005. Global consequences of land use. Science 309, 570-574, http://dx. doi.org/10.1126/science.1111772.

Folgarait, P.J., 1998. Ant biodiversity and its relationship to ecosystem functioning: a review. Biodivers. Conserv. 7, 1221-1244, http://dx.doi.org/10.1023/ A:1008891901953.

Fotso Kuate, A., Hanna, R., Tindo, M., Nanga, S., Nagel, P., 2015. Ant diversity in dominant vegetation types of Southern Cameroon. Biotropica 47, 94-100, http://dx.doi.org/10.1111/btp.12182.

Fowler, H.G., Forti, L.C., Brandao, C.R.F., Delabie, J.H.C., Vasconcelos, H.L., Panizzi, A.R., Parra, J.R.P., 1991. Ecologia nutricional de formigas. In: Oanizzi, A.R., Parra, J.R.P. (Eds.), Ecologia Nutricional de Insetos. Manole, São Paulo, pp. 131-223.

Gibb, H., Parr, C.L., 2013. Does structural complexity determine the morphology of assemblages? An experimental test on three continents. PLoS One 8, e64005, http://dx.doi.org/10.1371/journal.pone.0064005.

Gibb, H., Sanders, N.J., Dunn, R.R., Watson, S., Photakis, M., Abril, S., Andersen, A.N. Angulo, E., Armbrecht, I., Arnan, X., Baccaro, F.B., Bishop, T.R., Boulay, R. Castracani, C., Del Toro, I., Delsinne, T., Diaz, M., Donoso, D.A., Enriquez, M.L., Fayle, T.M., Feener, D.H., Fitzpatrick, M.C., Gomez, C., Grasso, D.A., Groc, S., Heterick, B., Hoffmann, B.D., Lach, L., Lattke, J., Leponce, M., Lessard, J.-P. Longino, J., Lucky, A., Majer, J., Menke, S.B., Mezger, D., Mori, A., Munyai, T.C., Paknia, O., Pearce-Duvet, J., Pfeiffer, M., Philpott, S.M., de Souza, J.L.P., Tista, M., Vasconcelos, H.L., Vonshak, M., Parr, C.L., 2015a. Climate mediates the effects of disturbance on ant assemblage structure. Proc. R. Soc. B 282, 20150418, http:// dx.doi.org/10.1098/rspb.2015.0418.

Gibb, H., Stoklosa, J., Warton, D.I., Brown, A.M., Andrew, N.R., Cunningham, S.A., 2015b. Does morphology predict trophic position and habitat use of ant species and assemblages? Oecologia 177, 519-531, http://dx.doi.org/10.1007/ s00442-014-3101-9.

Hölldobler, B., Wilson, E.O., 1990. The Ants. Harvard University Press.

Harrison, S., Bruna, E., 1999. Habitat fragmentation and large-scale conservation: what do we know for sure? Ecography 22, 225-232, http://dx.doi.org/10.1111/ j.1600-0587.1999.tb00496.x.

Harrison, X.A., 2014. Using observation-level random effects to model overdispersion in count data in ecology and evolution. PeerJ. 2, e616, http://dx. doi.org/10.7717/peerj.616.

Hill, M.O., Gauch, H.G., 1980. Detrended correspondence analysis: an improved ordination technique. Vegetatio 42, 47-58, http://dx.doi.org/10.1007/ BF00048870.

Hodkinson, I.D., 2005. Terrestrial insects along elevation gradients: species and community responses to altitude. Biol. Rev. 80, 489-513, http://dx.doi.org/10. $1017 /$ S1464793105006767. 
Hoffmann, B.D., Andersen, A.N., 2003. Responses of ants to disturbance in Australia, with particular reference to functional groups. Austral Ecol. 28, 444-464, http://dx.doi.org/10.1046/j.1442-9993.2003.01301.x.

Hoffmann, B.D., 2010. Using ants for rangeland monitoring: global patterns in the responses of ant communities to grazing. Ecol. Indic. 10, 105-111, http://dx doi.org/10.1016/j.ecolind.2009.04.016.

Holt, R.D., 1977. Predation, apparent competition, and the structure of prey communities. Theor. Popul. Biol. 12, 197-229, http://dx.doi.org/10.1016/00405809(77)90042-9.

Hooper, D.U., Chapin, F.S., Ewel, J.J., Hector, A., Inchausti, P., Lavorel, S., Lawton, J.H., Lodge, D.M., Loreau, M., Naeem, S., Schmid, B., Setälä, H., Symstad, A.J., Vandermeer, J., Wardle, D.A., 2005. Effects of biodiversity on ecosystem functioning: a consensus of current knowledge. Ecol. Monogr. 75, 3-35, http:// dx.doi.org/10.1890/04-0922.

Hothorn, T., Bretz, F., Westfall, P., 2008. Simultaneous inference in general parametric models. Biom. J. 50, 346-363, http://dx.doi.org/10.1002/bimj. 200810425 .

Howe, A., Lövei, G.L., Nachman, G., 2009. Dummy caterpillars as a simple method to assess predation rates on invertebrates in a tropical agroecosystem. Entomol. Exp. Appl. 131, 325-329, http://dx.doi.org/10.1111/j.1570-7458.2009.00860.x.

Hughes, L., 2000. Biological consequences of global warming: is the signal already apparent? Trends Ecol. Evol. 15, 56-61, http://dx.doi.org/10.1016/S01695347(99)01764-4.

Hunter, M.D., 2002. Landscape structure, habitat fragmentation, and the ecology of insects. Agric. For. Entomol. 4, 159-166, http://dx.doi.org/10.1046/j.14619563.2002.00152.x.

Hurlbert, A.H., Ballantyne, F., Powell, S., 2008. Shaking a leg and hot to trot: the effects of body size and temperature on running speed in ants. Ecol. Entomol. 33, 144-154, http://dx.doi.org/10.1111/j.1365-2311.2007.00962.x.

Jayatilaka, P., Narendra, A., Reid, S.F., Cooper, P., Zeil, J., 2011. Different effects of temperature on foraging activity schedules in sympatric Myrmecia ants. J. Exp. Biol. 214, 2730-2738, http://dx.doi.org/10.1242/jeb.053710.

Jenkins, C.N., Sanders, N.J., Andersen, A.N., Arnan, X., Brühl, C.A., Cerda, X., Ellison, A.M., Fisher, B.L., Fitzpatrick, M.C., Gotelli, N.J., Gove, A.D., Guénard, B., Lattke, J.E., Lessard, J.-P., McGlynn, T.P., Menke, S.B., Parr, C.L., Philpott, S.M., Vasconcelos, H.L., Weiser, M.D., Dunn, R.R., 2011. Global diversity in light of climate change: the case of ants. Divers. Distrib. 17, 652-662, http://dx.doi.org/ 10.1111/j.1472-4642.2011.00770.x.

Kaspari, M., Weiser, M.D., 1999. The size-grain hypothesis and interspecific scaling in ants. Funct. Ecol. 13, 530-538, http://dx.doi.org/10.1046/j.1365-2435.1999. 00343.x.

Kaspari, M., Alonso, L., O’Donnell, S., 2000. Three energy variables predict ant abundance at a geographical scale. Proc. R. Soc. B Biol. Sci. 267, 485-489, http://dx.doi.org/10.1098/rspb.2000.1026.

Kaspari, M., Yuan, M., Alonso, L., 2003. Spatial grain and the causes of regional diversity gradients in ants. Am. Nat. 161, 459-477, http://dx.doi.org/10.1086/ 367906.

Kaspari, M., 1996. Worker size and seed size selection by harvester ants in a neotropical forest. Oecologia 105, 397-404, http://dx.doi.org/10.1007/ BF00328743.

Kembel, S.W., Cowan, P.D., Helmus, M.R., Cornwell, W.K., Morlon, H., Ackerly, D.D. Blomberg, S.P., Webb, C.O., 2010. Picante: R tools for integrating phylogenies and ecology. Bioinformatics 26, 1463-1464, http://dx.doi.org/10.1093/ bioinformatics/btq166.

Klimes, P., Idigel, C., Rimandai, M., Fayle, T.M., Janda, M., Weiblen, G.D., Novotny, V., 2012. Why are there more arboreal ant species in primary than in secondary tropical forests? J. Anim. Ecol. 81, 1103-1112, http://dx.doi.org/10.1111/j. 1365-2656.2012.02002.x.

Klimes, P., Fibich, P., Idigel, C., Rimandai, M., 2015. Disentangling the diversity of arboreal ant communities in tropical forest trees. PLoS One 10, e0117853. http://dx.doi.org/10.1371/journal.pone.0117853.

Laliberté, E., Legendre, P., 2010. A distance-based framework for measuring functional diversity from multiple traits. Ecology 91, 299-305, http://dx.doi. org/10.1890/08-2244.1.

Lavergne, S., Mouquet, N., Thuiller, W., Ronce, O., 2010. Biodiversity and climate change: integrating evolutionary and ecological responses of species and communities. Annu. Rev. Ecol. Evol. Syst. 41, 321-350, http://dx.doi.org/10. 1146/annurev-ecolsys-102209-144628.

Lavorel, S., Garnier, E., 2002. Predicting changes in community composition and ecosystem functioning from plant traits: revisiting the Holy Grail. Funct. Ecol. 16, 545-556, http://dx.doi.org/10.1046/j.1365-2435.2002.00664.x.

Leal, I.R., Filgueiras, B.K.C., Gomes, J.P., Iannuzzi, L., Andersen, A.N., 2012. Effects of habitat fragmentation on ant richness and functional composition in Brazilian Atlantic forest. Biodivers. Conserv. 21, 1687-1701, http://dx.doi.org/10.1007/ s10531-012-0271-9.

Lebrija-Trejos, E., Pérez-García, E.A., Meave, J.A., Bongers, F., Poorter, L., 2010. Functional traits and environmental filtering drive community assembly in a species-rich tropical system. Ecology 91, 386-398, http://dx.doi.org/10.1890/ 08-1449.1.

Levings, S.C., 1983. Seasonal, annual, and among-site variation in the ground ant community of a deciduous tropical forest: some causes of patchy species distributions. Ecol. Monogr. 53, 435-455.

Longino, J.T., Branstetter, M.G., Colwell, R.K., 2014. How ants drop out: ant abundance on tropical mountains. PLoS One 9, e104030, http://dx.doi.org/10. 1371/journal.pone.0104030.
Low, P.A., Sam, K., McArthur, C., Posa, M.R.C., Hochuli, D.F., 2014. Determining predator identity from attack marks left in model caterpillars: guidelines for best practice. Entomol. Exp. Appl. 152, 120-126, http://dx.doi.org/10.1111/eea. 12207.

Low, P.A., McArthur, C., Hochuli, D.F., 2016. It is safe to go out on a limb: within-tree leaf age and location do not alter predation risk for insect herbivores. Austral Entomol. 55, 284-290, http://dx.doi.org/10.1111/aen.12183.

Machac, A., Janda, M., Dunn, R.R., Sanders, N.J., 2011. Elevational gradients in phylogenetic structure of ant communities reveal the interplay of biotic and abiotic constraints on diversity. Ecography 34, 364-371, http://dx.doi.org/10 1111/j.1600-0587.2010.06629.x.

Medeiros, J., Azevedo, D.L.O., Santana, M.A.D., Lopes, T.R.P., Araújo, A., 2014. Foraging activity rhythms of Dinoponera quadriceps (Hymenoptera: Formicidae) in its natural environment. J. Insect Sci. 14, 220, http://dx.doi.org/ $10.1093 /$ jisesa/ieu082.

Meinshausen, M., Smith, S.J., Calvin, K., Daniel, J.S., Kainuma, M.L.T., Lamarque, J.-F., Matsumoto, K., Montzka, S.A., Raper, S.C.B., Riahi, K., Thomson, A., Velders, G.J.M., van Vuuren, D.P.P., 2011. The RCP greenhouse gas concentrations and their extensions from 1765 to 2300 . Clim. Change 109, 213-241, http://dx.doi. org/10.1007/s10584-011-0156-Z.

Meyer, S.T., Koch, C., Weisser, W.W., 2015. Towards a standardized rapid ecosystem function assessment (REFA). Trends Ecol. Evol. 30, 390-397, http:// dx.doi.org/10.1016/j.tree.2015.04.006.

Molleman, F., Remmel, T., Sam, K., 2016. Phenology of predation on insects in a tropical forest: temporal variation in attack rate on dummy caterpillars. Biotropica 48, 229-236, http://dx.doi.org/10.1111/btp.12268.

Mouchet, M.A., Villéger, S., Mason, N.W.H., Mouillot, D., 2010. Functional diversity measures: an overview of their redundancy and their ability to discriminate community assembly rules. Funct. Ecol. 24, 867-876, http://dx.doi.org/10. $1111 /$ j.1365-2435.2010.01695.x.

Noss, R.F., 1999. Assessing and monitoring forest biodiversity: a suggested framework and indicators. For. Ecol. Manage. 115, 135-146, http://dx.doi.org/ 10.1016/S0378-1127(98)00394-6.

Nowrouzi, S., Andersen, A.N., Macfadyen, S., Staunton, K.M., VanDerWal, J., Robson, S.K.A., 2016. Ant diversity and distribution along elevation gradients in the Australian wet tropics: the importance of seasonal moisture stability. PLoS One 11, e0153420, http://dx.doi.org/10.1371/journal.pone.0153420.

Oksanen, J., Blanchet, F.G., Kindt, R., Legendre, P., Minchin, P.R., O’Hara, R.B., Simpson, G.L., Solymos, P., Stevens, M.H.H., Wagner, H., 2016. Vegan: Community Ecology Package.

Pace, M.L., Cole, J.J., Carpenter, S.R., Kitchell, J.F., 1999. Trophic cascades revealed in diverse ecosystems. Trends Ecol. Evol. 14, 483-488, http://dx.doi.org/10.1016/ S0169-5347(99)01723-1.

Palmer, M.A., Febria, C.M., 2012. The heartbeat of ecosystems. Science 336, 1393-1394, http://dx.doi.org/10.1126/science.1223250.

Parr, C.L., Eggleton, P., Davies, A.B., Evans, T.A., Holdsworth, S., 2016. Suppression of savanna ants alters invertebrate composition and influences key ecosystem processes. Ecology 97, 1611-1617, http://dx.doi.org/10.1890/15-1713.1.

Peacor, S.D., Werner, E.E., 2001. The contribution of trait-mediated indirect effects to the net effects of a predator. PNAS 98, 3904-3908, http://dx.doi.org/10. 1073/pnas.071061998.

Peters, T., Drobnik, T., Meyer, H., Rankl, M., Richter, M., Rollenbeck, R., Thies, B., Bendix, J., 2013. Environmental changes affecting the Andes of Ecuador. In: Bendix, J., Beck, E., Bräuning, A., Makeschin, F., Mosandl, R., Scheu, S., Wilcke, W. (Eds.), Ecosystem Services, Biodiversity and Environmental Change in a Tropical Mountain Ecosystem of South Ecuador, Ecological Studies. Springer, Berlin, Heidelberg, pp. 19-29, http://dx.doi.org/10.1007/978-3-642-38137-9_2.

Peters, M.K., Mayr, A., Röder, J., Sanders, N.J., Steffan-Dewenter, I., 2014. Variation in nutrient use in ant assemblages along an extensive elevational gradient on $\mathrm{Mt}$ Kilimanjaro. J. Biogeogr. 41, 2245-2255, http://dx.doi.org/10.1111/jbi.12384.

Philpott, S.M., Perfecto, I., Armbrecht, I., Parr, C.L., 2010. Ant diversity and function in disturbed and changing habitats. In: Lach, L., Parr, C.L., Abbott, K.L. (Eds.), Ant Ecology. Oxford University Press, pp. 137-156, http://dx.doi.org/10.1093/ acprof:oso/9780199544639.003.0008.

Pickett, S.T.A., 1989. Space-for-time substitution as an alternative to long-term studies. In: Likens, G.E. (Ed.), Long-Term Studies in Ecology: Approaches and Alteratives. Springer, New York, pp. 110-135, http://dx.doi.org/10.1007/978-1 4615-7358-6_5.

Raimundo, R., Freitas, A., Oliveira, P., 2009. Seasonal patterns in activity rhythm and foraging ecology in the Neotropical forest-dwelling ant, Odontomachus chelifer (Formicidae: Ponerinae). Ann. Entomol. Soc. Am. 102, 1151-1157, http://dx.doi.org/10.1603/008.102.0625.

Ratnasingham, S., Hebert, P.D.N., 2007. BOLD: the barcode of life data system (http://www.barcodinglife.org). Mol. Ecol. Notes 7, 355-364, http://dx.doi.org/ 10.1111/j.1471-8286.2007.01678.x.

Read, J.L., Andersen, A.N., 2000. The value of ants as early warning bioindicators: responses to pulsed cattle grazing at an Australian arid zone locality. J. Arid Environ. 45, 231-251, http://dx.doi.org/10.1006/jare.2000.0634.

Reymond, A., Purcell, J., Cherix, D., Guisan, A., Pellissier, L., 2013. Functional diversity decreases with temperature in high elevation ant fauna. Ecol. Entomol. 38, 364-373, http://dx.doi.org/10.1111/een.12027.

Ricotta, C., Carboni, M., Acosta, A.T.R., 2015. Let the concept of indicator species be functional! J. Veg. Sci. 26, 839-847, http://dx.doi.org/10.1111/jvs.12291.

Rollenbeck, R., Bendix, J., 2011. Rainfall distribution in the Andes of southern Ecuador derived from blending weather radar data and meteorological field 
observations. Atmos. Res. 99, 277-289, http://dx.doi.org/10.1016/j.atmosres. 2010.10.018.

Ryder Wilkie, K.T., Mertl, A.L., Traniello, J.F.A., 2009. Diversity of ground-dwelling ants (Hymenoptera: Formicidae) in primary and secondary forests in Amazonian Ecuador. Myrmecol. News 12, 139-147.

Salazar, F., Reyes-Bueno, F., Sanmartin, D., Donoso, D.A., 2015. Mapping continental Ecuadorian ant species. Sociobiology 62, 132-162, http://dx.doi.org/10.13102/ sociobiology.v62i2.132-162.

Sam, K., Koane, B., Novotny, V., 2015a. Herbivore damage increases avian and ant predation of caterpillars on trees along a complete elevational forest gradient in Papua New Guinea. Ecography 38, 293-300, http://dx.doi.org/10.1111/ecog. 00979.

Sam, K., Remmel, T., Molleman, F., 2015b. Material affects attack rates on dummy caterpillars in tropical forest where arthropod predators dominate: an experiment using clay and dough dummies with green colourants on various plant species. Entomol. Exp. Appl. 157, 317-324, http://dx.doi.org/10.1111/eea. 12367.

Sanders, N.J., Moss, J., Wagner, D., 2003. Patterns of ant species richness along elevational gradients in an arid ecosystem. Glob. Ecol. Biogeogr. 12, 93-102, http://dx.doi.org/10.1046/j.1466-822X.2003.00324.x.

Sanders, N.J., Lessard, J.-P., Fitzpatrick, M.C., Dunn, R.R., 2007. Temperature, but not productivity or geometry, predicts elevational diversity gradients in ants across spatial grains. Glob. Ecol. Biogeogr. 16, 640-649, http://dx.doi.org/10. $1111 /$ j.1466-8238.2007.00316.x.

Schoereder, J.H., Sobrinho, T.G., Ribas, C.R., Campos, R.B.F., 2004. Colonization and extinction of ant communities in a fragmented landscape. Austral Ecol. 29, 391-398, http://dx.doi.org/10.1111/j.1442-9993.2004.01378.x.

Scholes, R.J., Mace, G.M., Turner, W., Geller, G.N., Jurgens, N., Larigauderie, A. Muchoney, D., Walther, B.A., Mooney, H.A., 2008. Toward a global biodiversity observing system. Science 321, 1044-1045, http://dx.doi.org/10.1126/science. 1162055.

Seifert, C.L., Schulze, C.H., Dreschke, T.C.T., Frötscher, H., Fiedler, K., 2016. Day vs. night predation on artificial caterpillars in primary rainforest habitats - an experimental approach. Entomol. Exp. Appl. 158, 54-59, http://dx.doi.org/10. $1111 /$ eea.12379.

Shipley, B., 2009. Confirmatory path analysis in a generalized multilevel context. Ecology 90, 363-368, http://dx.doi.org/10.1890/08-1034.1.

Siddig, A.A.H., Ellison, A.M., Ochs, A., Villar-Leeman, C., Lau, M.K., 2016. How do ecologists select and use indicator species to monitor ecological change? Insights from 14 years of publication in Ecological Indicators. Ecol. Indic. 60 223-230, http://dx.doi.org/10.1016/j.ecolind.2015.06.036.

Snyder, W.E., Snyder, G.B., Finke, D.L., Straub, C.S., 2006. Predator biodiversity strengthens herbivore suppression. Ecol. Lett. 9, 789-796, http://dx.doi.org/10. 1111/j.1461-0248.2006.00922.x.
Stern, D., Emlen, D., 1999. The developmental basis for allometry in insects. Development 126, 1091-1101.

Stuart-Smith, R.D., Bates, A.E., Lefcheck, J.S., Duffy, J.E., Baker, S.C., Thomson, R.J., Stuart-Smith, J.F. Hill, N.A., Kininmonth, S.J., Airoldi, L., Becerro, M.A. Campbell, S.J., Dawson, T.P., Navarrete, S.A., Soler, G.A., Strain, E.M.A., Willis, T.J., Edgar, G.J., 2013. Integrating abundance and functional traits reveals new global hotspots of fish diversity. Nature 501, 539-542, http://dx.doi.org/10. 1038/nature12529.

Tilman, D., Reich, P.B., Isbell, F., 2012. Biodiversity impacts ecosystem productivity as much as resources, disturbance, or herbivory. Proc. Natl. Acad. Sci. U. S. A. 109, 10394-10397, http://dx.doi.org/10.1073/pnas.1208240109.

Tu, Y.-K., Kellett, M., Clerehugh, V., Gilthorpe, M.S., 2005. Problems of correlations between explanatory variables in multiple regression analyses in the dental literature. Br. Dent. J. 199, 457-461, http://dx.doi.org/10.1038/sj.bdj.4812743.

Underwood, E.C., Fisher, B.L., 2006. The role of ants in conservation monitoring: if, when, and how. Biol. Conserv. 132, 166-182, http://dx.doi.org/10.1016/j. biocon.2006.03.022.

Villéger, S., Mason, N.W.H., Mouillot, D., 2008. New multidimensional functional diversity indices for a multifaceted framework in functional ecology. Ecology 89, 2290-2301, http://dx.doi.org/10.1890/07-1206.1.

Vogt, J.T., Smith, W. a., Grantham, R.A., Wright, R.E., 2003. Effects of temperature and season on foraging activity of red imported fire ants (Hymenoptera: Formicidae) in Oklahoma. Environ. Entomol. 32, 447-451, http://dx.doi.org/10. 1603/0046-225X-32.3.447.

Walther, G.R., 2010. Community and ecosystem responses to recent climate change. Philos. Trans. R. Soc. B Biol. Sci. 365, 2019-2024, http://dx.doi.org/10. 1098/rstb.2010.0021.

Weiser, M.D., Kaspari, M., 2006. Ecological morphospace of new world ants. Ecol. Entomol. 31, 131-142, http://dx.doi.org/10.1111/j.0307-6946.2006.00759.x.

Wiescher, P.T., Pearce-Duvet, J.M.C., Feener, D.H., 2012. Assembling an ant community: species functional traits reflect environmental filtering. Oecologia 169, 1063-1074, http://dx.doi.org/10.1007/s00442-012-2262-7.

Woodcock, P., Edwards, D.P., Fayle, T.M., Newton, R.J., Khen, C.V., Bottrell, S.H., Hamer, K.C., 2011. The conservation value of South East Asia's highly degraded forests: evidence from leaf-litter ants. Philos. Trans. R. Soc. B Biol. Sci. 366, 3256-3264, http://dx.doi.org/10.1098/rstb.2011.0031.

Yanoviak, S.P., Kaspari, M., 2000. Community structure and the habitat templet: ants in the tropical forest canopy and litter. Oikos 89, 259-266, http://dx.doi. org/10.1034/j.1600-0706.2000.890206.x.

Yates, M.L., Andrew, N.R., Binns, M., Gibb, H., 2014. Morphological traits: predictable responses to macrohabitats across a $300 \mathrm{~km}$ scale. PeerJ. 2, e271, http://dx.doi.org/10.7717/peerj.271.

Yusah, K.M., Foster, W.A., 2016. Tree size and habitat complexity affect ant communities (Hymenoptera: Formicidae) in the high canopy of Bornean rain forest. Myrmecol. News 23, 15-23. 